\title{
Implementasi Konsep Health Belief Model terhadap Asupan Antioksidan Mahasiswa Gizi selama Pandemi COVID-19
}

\author{
Farah Nuriannisa ${ }^{1}$, Kartika Yuliani ${ }^{2}$ \\ ${ }^{1,2}$ Program Studi S1 Gizi, Universitas Nahdlatul Ulama, Surabaya, Indonesia \\ farahnuri@unusa.ac.id
}

\begin{abstract}
Many recommendations were made by the Indonesia's government to prevent the occurrence of COVID-19 infection. One of those recommendations is to make several behavioural changes, such as increasing the consumption of foods containing vitamin $A, C, E$, and zinc to increase immunity system in the body. These eating pattern can be influenced by several factors, such as individual perceptions. The purpose of this study was to determine the relationship between the concept of the health belief model and the eating pattern of Nutrition Students of UNUSA during the COVID-19 pandemic. Method of this study was analytic observational study with cross sectional design. The instruments used in this study were online questionnaire regarding the health belief model and semi-quantitative food frequency questionnaire (SQFFQ). All respondents had a high perception of the seriousness of the COVID-19 disease, benefits in increasing consumption of healthy foods, support for eating healthy foods, and self efficacy to adopt healthy eating pattern. $47.8 \%$ of respondents had a low perception of barriers to healthy behavior, while $65.5 \%$ of respondents had a high perception of susceptibility to COVID-19 infection. Most of the respondents had adequate daily intake of vitamin $A(93.8 \%)$ and vitamin $C(74.3 \%)$. There was a difference in vitamin $C$ intake between the group with high perceived barrier and the low perceived barrier group ( $p$ value 0.037). There was significantly negative relationship between perceived barrier and vitamin E intake in the subjects, which means that if a person has higher barriers to consuming vitamin E, the person's vitamin E intake will also be lower.
\end{abstract}

Keywords : COVID-19, health belief model, antioxidant, eating pattern

\section{PENDAHULUAN}

Saat ini, jutaan penduduk di berbagai negara di belahan dunia tengah terjangkit suatu penyakit yang berasal dari suatu jenis coronavirus baru, atau umum disebut dengan coronavirus disease-19 (COVID-19). Hingga saat ini, data dari World Health Organization (WHO) (2020) menunjukkan sekitar 24,8 juta orang positif terinfeksi, dengan angka kematian sebesar 838,9 ribu orang. Di Indonesia, sekitar 172,05 ribu orang telah terkonfirmasi positif COVID-19 dengan angka kematian sekitar 7,3 ribu orang. Peningkatan jumlah pasien secara masal umum ditemui di berbagai negara, dimana hal ini disebabkan oleh transmisi virus COVID-19 yang terjadi secara masif (Wu et al., 2020). Seperti yang telah diketahui, virus COVID-19 ini menyebabkan terjadinya gangguan pada sistemik tubuh, terutama organ respirasi atau pernafasan, sehingga menyebabkan berbagai penanda proinflamasi meningkat, seperti interleukin-1, interleukin-7, interleukin-8, dan tumor-necrosis factor- $\alpha$, sehingga hal tersebut mengakibatkan kegagalan organ dan kematian (Rothan \& Byrareddy, 2020). Adanya transmisi yang cepat dan peningkatan kasus baru serta kematian 
tersebut, WHO resmi mendeklarasikan COVID19 ini sebagai wabah pandemik pada 11 Maret 2020.

Menyusul kebijakan pendeklarasian COVID-19 sebagai masalah kesehatan global tersebut, kampanye dan promosi kesehatan mengenai COVID-19 juga dilakukan oleh berbagai instansi untuk meningkatkan awareness masyarakat mengenai kerentanan dan bahaya COVID-19 ini sehingga masyarakat akan mengubah perilaku mereka menjadi lebih sehat. Perubahan perilaku dapat dipengaruhi oleh beberapa faktor, dimana beberapa faktor tersebut tertuang dalam konsep teori health belief model, meliputi persepsi kerentanan terhadap penyakit (perceived susceptibility), persepsi keparahan penyakit (perceived severity), manfaat bila melakukan perilaku tersebut (perceived benefit), hambatan yang mungkin dihadapi saat berperilaku (perceived barriers), strategi untuk mengubah perilaku (cues to action), dan kepercayaan diri untuk mengubah perilaku (self efficacy) (Jones et al., 2015).. Salah satu perilaku kesehatan, terutama gizi, yang dapat dilakukan untuk mencegah penularan COVID-19 ini adalah dengan memperhatikan asupan gizi. Asupan gizi yang kurang, baik secara kuantitas dan kualitas, dapat menyebabkan imunitas (daya tahan tubuh) menurun, sehingga akan rawan terserang penyakit, terutama penyakit infeksi (Syam et al., 2013). Penting untuk mengonsumsi aneka ragam makanan agar semua kebutuhan dapat tercukupi dan imunitas tubuh tetap terjaga

Menurut Muscogiuri et al. (2020), zat gizi Jurnal Gizi Unimus Vol 10 No 12021 yang banyak berhubungan dengan imunitas adalah vitamin $\mathrm{A}$, vitamin $\mathrm{C}$, vitamin $\mathrm{E}$, dan zink. Vitamin $\mathrm{A}$, vitamin $\mathrm{C}$, vitamin $\mathrm{E}$, dan zink merupakan zat antioksidan yang dapat meningkatkan subset dari sel $\mathrm{T}$ (berhubungan dengan sistem imun), meningkatkan respon limfosit sebagai salah satu komponen imunitas, serta memodulasi pengaktifan natural killer (NK) cells, yang merupakan first line dari sistem pertahanan tubuh dalam menghadapi infeksi virus. Kebutuhan vitamin A yang dianjurkan adalah sebanyak $600 \mu \mathrm{g} / \mathrm{hari}$ pada dewasa (19-29 tahun) (Handayani, 2020). Asupan vitamin C yang dianjurkan adalah sebanyak $75 \mathrm{mg} / \mathrm{hari}$, sedangkan anjuran konsumsi vitamin $\mathrm{E}$ adalah sebesar $8 \mathrm{mg} / \mathrm{hari}$, dan asupan zink dengan anjuran sebanyak 10 mg/hari (Handayani, 2020). Sebagai kelompok masyarakat yang telah mempelajari ilmu dan mengetahui kandungan zat gizi dalam suatu bahan makanan, mahasiswa Gizi UNUSA tentunya telah memahami zat gizi dan manfaatnya dalam kesehatan. Selain itu, sebagai calon tenaga kesehatan, para mahasiswa Gizi diharapkan juga mampu menjadi sosok role model perilaku makan bagi masyarakat, terutama perilaku makan yang berkaitan dengan suatu penyakit. Karakteristik mahasiswa sebagai remaja juga berdampak pada adanya perubahan pengaruh kebiasaan makan, dimana umumnya pemilihan makanan ditentukan sendiri oleh remaja. Berdasarkan hal tersebut, peneliti tertarik untuk meneliti persepsi mahasiswa gizi terkait COVID-19 serta hubungannya terhadap implementasi dan perilaku makan mereka sebagai 
salah satu upaya pencegahan COVID-19.

\section{METODE PENELITIAN}

Penelitian ini merupakan penelitian observasi analitik dengan desain cross sectional. Populasi yang digunakan dalam penelitian ini adalah mahasiswa semester dua, empat, dan enam Program Studi S1 Gizi Universitas Nahdlatul Ulama Surabaya. Berdasarkan perhitungan jumlah sampel minimal menggunakan rumus hypothesis tests for two population proportions dari Lemeshow et al., (1990) dengan pertimbangan penelitian serupa dari Trisnawan (2015), diperoleh jumlah sampel minimal adalah 103 orang. Jumlah sampel minimal ini kemudian ditambahkan dengan cadangan drop out sebanyak $10 \%$ (10 orang), sehingga total sampel yang didapatkan adalah 113 orang. Proses pemilihan sampel dilakukan secara simple random sampling karena populasi dapat dikatakan telah homogen. Adapun kriteria inklusi yang ditentukan adalah sehat jasmani dan rohani (tidak sedang mengalami penyakit infeksi maupun penyakit degeneratif), memiliki smartphone yang berfungsi dengan baik, dan bersedia mengikuti penelitian. Kriteria eksklusi yang ditentukan adalah sedang menjalani diet khusus penyakit, memiliki kelainan absorbsi atau intoleransi terhadap vitamin $\mathrm{A}$, vitamin $\mathrm{C}$, vitamin E, dan zink. Instrumen penelitian yang digunakan adalah kuesioner health belief model dan semi-quantitative food-frequency questionnaire (SQ-FFQ).

Kuesioner health belief model digunakan untuk mengetahui persepsi responden mengenai COVID-19. Pertanyaan yang tercantum dalam Jurnal Gizi Unimus Vol 10 No 12021 kuesioner tersebut berjumlah 30 pertanyaan dan terdiri dari enam bagian, yaitu perceived susceptibility, perceived severity, perceived benefit, perceived barrier, cues to action, dan self efficacy. Persepsi responden diukur dengan menggunakan skala Likert, yang terdiri dari sangat tidak setuju (skala 1), tidak setuju (skala 2), setuju (skala 3), dan sangat setuju (skala 4). Kuesioner health belief model yang digunakan telah diuji validitas dengan rentang nilai 0,517 0,810 dan uji reliabilitas dengan hasil Cronbach's alpha 0,620-0,811.

Kuesioner SQ-FFQ digunakan untuk mengetahui asupan vitamin $\mathrm{A}$, vitamin $\mathrm{C}$, vitamin E, dan zink. Kuesioner ini terdiri dari 61 daftar bahan makanan sumber vitamin $A$, vitamin $C$, vitamin E, dan zink. Hasil kuesioner SQ-FFQ berupa frekuensi dan jumlah konsumsi bahan makanan sumber vitamin $A$, vitamin $C$, vitamin $E$, dan zink pada responden akan diinput dan diolah dengan software Nutrisurvey.

Seluruh proses pengumpulan data dilakukan secara daring (online). Hasil data yang telah terkumpul dianalisis menggunakan uji beda Mann Whitney dan korelasi Rank Spearman dalam software Statistical Package for the Social Sciences (SPSS) versi 26. Penelitian ini telah mendapatkan persetujuan laik etik dari Komite Etik Penelitian Kesehatan Universitas Nahdlatul Ulama Surabaya dengan nomor 153/EC/KEPK/UNUSA/2020.

\section{HASIL DAN PEMBAHASAN}

Penelitian ini melibatkan 113 responden yang terdiri dari 38 mahasiswa semester enam, 35 
mahasiswa semester empat, dan 40 responden semester dua. Karakteristik responden dapat dilihat pada Tabel 1 berikut.

Tabel 1. Karakteristik Responden Penelitian

\begin{tabular}{lc}
\hline \multicolumn{1}{c}{ Karakteristik } & Jumlah $(\%)$ \\
\hline Jenis Kelamin & $113(100)$ \\
Perempuan & $0(0)$ \\
Laki-laki & \\
Usia (tahun) & $37(32,8)$ \\
$18-19$ & $65(57,5)$ \\
$20-21$ & $11(9,7)$ \\
$22-23$ & $110(97,3)$ \\
Domisili & $3(2,7)$ \\
Jawa Timur & $112(99,1)$ \\
Luar Jawa Timur & $1(0,9)$ \\
Status Tinggal Saat Ini & \\
Bersama Orangtua/Keluarga & \\
Sendiri (Kos) &
\end{tabular}

Berdasarkan data karakteristik responden, rerata usia responden 20.05 tahun dan $100 \%$ berjenis kelamin perempuan. Saat ini sebanyak 112 responden tinggal dengan orang tua atau keluarga, sedangkan satu responden tinggal sendiri (kos). Sebagian besar responden $(97,3 \%)$ berdomisili di Jawa Timur (Surabaya, Sidoarjo, Gresik, Mojokerto, Sumenep, Bangkalan, Bojonegoro, Magetan, Tulungagung, dan Probolinggo) dan 2,7\% responden (tiga orang) berdomisili di Lombok, Riau, dan Pontianak. Pengambilan seluruh data responden dilakukan secara daring (online).

\section{Data Persepsi Responden (Health Belief Model)}

Data persepsi responden mengenai penyakit COVID-19 dan perilaku makan sehat yang diukur menggunakan kuesioner health belief model dapat dilihat pada Tabel 2 di bawah ini.
Tabel 2. Hasil Persepsi yang Dimiliki Responden

\begin{tabular}{lcc}
\hline & \multicolumn{2}{c}{$\begin{array}{c}\text { Kategori Persepsi } \\
(\mathrm{n}(\%))\end{array}$} \\
\hline & $\begin{array}{c}\text { Persepsi } \\
\text { Rendah }\end{array}$ & $\begin{array}{c}\text { Persepsi } \\
\text { Tinggi }\end{array}$ \\
\hline $\begin{array}{l}\text { Persepsi kerentanan } \\
\text { (perceived }\end{array}$ & $39(34.5)$ & $74(65.5)$ \\
$\begin{array}{l}\text { susceptibility) } \\
\text { Persepsi keseriusan } \\
\text { (perceived severity) }\end{array}$ & $0(0)$ & $113(100)$ \\
$\begin{array}{l}\text { Persepsi manfaat } \\
\text { (perceived benefit) }\end{array}$ & $0(0)$ & $113(100)$ \\
$\begin{array}{l}\text { Persepsi hambatan } \\
\text { (perceived barrier) }\end{array}$ & $59(52.2)$ & $54(47.8)$ \\
$\begin{array}{l}\text { Persepsi dukungan } \\
\text { untuk berperilaku } \\
\text { (cues to action) }\end{array}$ & $0(0)$ & $113(100)$ \\
$\begin{array}{l}\text { Kepercayaan diri } \\
\text { untuk berperilaku } \\
\text { (self-efficacy) }\end{array}$ & $0(0)$ & $113(100)$ \\
\hline
\end{tabular}

Dari Tabel 2, diketahui 100\% responden memiliki persepsi yang tinggi terhadap keseriusan dari penyakit COVID-19 (perceived severity), manfaat dalam meningkatkan konsumsi makanan sehat (perceived benefit), dukungan untuk mengonsumsi makanan sehat (cues to action), serta kepercayaan diri untuk menerapkan perilaku makan sehat (self efficacy). Berdasarkan hasil penelitian ini, diketahui bahwa sebanyak $65,5 \%$ responden merasa rentan untuk terkena COVID19. Hal ini dapat disebabkan karena sebagian besar responden $(62,8 \%)$ tinggal di Surabaya dan Sidoarjo yang merupakan zona merah dari COVID-19 saat proses pengambilan data dilakukan. Selain itu, dari hasil pengambilan data juga diketahui bahwa sekitar $47,8 \%$ responden merasa terhambat untuk mengonsumsi makanan sumber vitamin $A$, vitamin $C$, vitamin $E$, dan zink. Hasil kuesioner menyebutkan bahwa hambatan yang paling sering dirasakan oleh responden adalah kurangnya biaya untuk membeli makanan 
sumber vitamin $\mathrm{A}$, vitamin $\mathrm{C}$, vitamin $\mathrm{E}$, dan zink secara mandiri, sehingga mereka harus menunggu orang tua untuk membeli makanan tersebut. Sebanyak $100 \%$ responden memiliki persepsi tinggi terhadap keseriusan penyakit COVID-19 (takut menularkan virus COVID-19 ke keluarga dan harus menjalani isolasi mandiri), manfaat mengonsumsi makanan tinggi antioksidan (untuk mencegah infeksi COVID-19 dengan cara meningkatkan sistem imun), dukungan untuk mengonsumsi makanan tinggi antioksidan (pemberian informasi dan promosi kesehatan di berbagai media), serta kepercayaan diri untuk menerapkan perilaku makan sehat atau tinggi antioksidan (mampu untuk mengonsumsi buah dan sayur serta lauk hewani di setiap kali makan dan mengetahui jumlah zat gizi dalam bahan makanan sehingga lebih memudahkan untuk mengatur makan).

Asupan Vitamin A, C, E, dan Zink pada Responden

Secara garis besar, jumlah konsumsi vitamin $\mathrm{A}$, vitamin $\mathrm{C}$, vitamin $\mathrm{E}$, dan zink dapat dikategorikan dengan "asupan cukup" bila asupan telah sesuai atau melebihi kebutuhan per hari dan “asupan kurang" bila asupan kurang dari kebutuhan per hari. Dari Tabel 3, dapat dilihat data asupan vitamin A, vitamin C, vitamin E, dan zink pada responden, dimana sebagian besar responden memiliki asupan vitamin A $(93,8 \%)$ dan vitamin C (74,3\%) yang cukup atau sesuai kebutuhan per hari, sedangkan asupan vitamin $\mathrm{E}$ $(82,3 \%)$ dan zink $(75,3 \%)$ pada responden sebagian besar tergolong kurang.

Jurnal Gizi Unimus Vol 10 No 12021
Tabel 3. Asupan Vitamin A, Vitamin C, Vitamin

E, dan Zink Responden Penelitian

\begin{tabular}{cccc}
\hline \multirow{2}{*}{$\begin{array}{c}\text { Jenis } \\
\text { Asupan }\end{array}$} & Median & \multicolumn{2}{c}{$\begin{array}{c}\text { Kategori Asupan } \\
(\mathrm{n}(\%))\end{array}$} \\
\cline { 3 - 4 } & & $\begin{array}{c}\text { Asupan } \\
\text { Kurang }\end{array}$ & $\begin{array}{c}\text { Asupan } \\
\text { Cukup }\end{array}$ \\
\hline Vitamin & 1626.1 & $7(6.2)$ & 106 \\
A & $\mu \mathrm{g} / \mathrm{hari}$ & & $(93.8)$ \\
Vitamin & 161.6 & $29(25.7)$ & $84(74.3)$ \\
C & $\mathrm{mg} / \mathrm{hari}$ & & \\
Vitamin & 5.2 & $93(82.3)$ & $20(17.7)$ \\
E & $\mathrm{mg} /$ hari & & \\
Zink & 5.23 & $85(75.2)$ & $28(24.8)$ \\
\hline
\end{tabular}

Berdasarkan data kuesioner SQ-FFQ, sebagian besar responden memiliki asupan makanan sumber vitamin A dan $\mathrm{C}$ yang cukup atau sesuai dengan kebutuhan, namun sebagian besar responden ternyata masihkurang mengonsumsi sumber vitamin E dan zink. Hasil tersebut sejalan dengan penelitian oleh Regi et al. (2017), dimana asupan vitamin C pada ibu hamil termasuk cukup, sedangkan vitamin E dan zink dalam kategori kurang. Hal ini mungkin dapat disebabkan karena vitamin $\mathrm{E}$ dan zink banyak terdapat pada bahan makanan yang jarang dikonsumsi sehari-hari dalam jumlah besar, seperti kacang-kacangan (kacang mete, kacang tanah, kacang kedelai), daging hewan (kambing, sapi, ikan, dan seafood), serta minyak (minyak wijen, minyak kelapa, dan minyak ikan). Selain itu, produk suplementasi vitamin A dan vitamin C yang dijual dan beredar di masyarakat lebih banyak dan beragam dibandingkan dengan produk suplementasi vitamin E dan zink. Vitamin dan mineral merupakan zat gizi yang tidak dapat diproduksi oleh tubuh manusia padahal kedua zat 
tersebut berperan penting dalam sistem imunitas tubuh, sehingga kebutuhan vitamin dan mineral harus dipenuhi dari makanan yang seimbang dan bervariasi serta asupan suplementasi bila dibutuhkan (Siswanto et al., 2013). Asupan vitamin dan mineral, terutama vitamin $\mathrm{A}, \mathrm{C}, \mathrm{E}$, dan zink, pada masa pandemi COVID-19 ini harus diperhatikan karena komponen tersebut memiliki sifat sebagai antioksidan. Antioksidan dapat membantu meningkatkan respon limfosit tubuh untuk merespon adanya mitogen serta meningkatkan produksi interleukin-2 yang berperan sebagai antiinflamasi (Muscogiuri et al., 2020).

\section{Hubungan Persepsi Individu dengan Asupan}

\section{Vitamin A, C, E, dan Zink}

Seperti yang telah dijelaskan sebelumnya, seluruh responden memiliki persepsi keseriusan, persepsi manfaat, persepsi dukungan untuk berperilaku, serta kepercayaan diri untuk berperilaku yang tinggi, sehingga tidak dapat dilakukan uji beda terhadap asupan antioksidan. Pada Tabel 4 berikut, terlihat bahwa pada kelompok responden yang memiliki persepsi hambatan tinggi mengonsumsi vitamin $\mathrm{C}$ lebih sedikit dibandingkan kelompok responden yang memiliki persepsi hambatan rendah ( $p$ value $<$ $0,05)$.
Tabel 4. Hasil Uji Beda Tingkat Persepsi dengan Asupan Vitamin A, C, E, dan Zink pada Responden

\begin{tabular}{|c|c|c|c|c|c|}
\hline & \multicolumn{4}{|c|}{ Median Asupan } \\
\hline & & Vit A & Vit C & Vit E & $\mathrm{Zn}$ \\
\hline \multirow{2}{*}{$\begin{array}{c}\text { Persepsi } \\
\text { kerentanan } \\
\text { (perceived } \\
\text { susceptibi- } \\
\text { lity) }\end{array}$} & $\begin{array}{c}\text { Rendah } \\
\text { (n: 39) }\end{array}$ & 1605,9 & 104,8 & 6,1 & 5,9 \\
\hline & $\begin{array}{l}\text { Tinggi } \\
\text { (n: 74) }\end{array}$ & 1669,7 & 179,1 & 5 & 5,22 \\
\hline \multicolumn{2}{|c|}{$\mathrm{p}$-value $\mathrm{a}^{\mathrm{a}}$} & 0,69 & 0,12 & 0,76 & 0,98 \\
\hline \multirow{3}{*}{$\begin{array}{c}\text { Persepsi } \\
\text { hambatan } \\
\text { (perceived } \\
\text { barrier) } \\
\text { p-va }\end{array}$} & $\begin{array}{c}\text { Rendah } \\
\text { (n: 59) }\end{array}$ & 1745 & 193,8 & 7 & 5,4 \\
\hline & $\begin{array}{l}\text { Tinggi } \\
\text { (n: 54) }\end{array}$ & 1546,7 & 107,8 & 4,5 & 4,4 \\
\hline & & 0,48 & $0,04^{*}$ & 0.09 & 0,5 \\
\hline
\end{tabular}

Dari uji hubungan yang dilakukan pada persepsi kerentanan dan persepsi hambatan terhadap asupan vitamin A, C, E, dan zink pada Tabel 5, ditemukan bahwa persepsi hambatan memiliki hubungan negatif yang signifikan dengan asupan vitamin E pada responden. Hal ini menjelaskan bahwa semakin tinggi hambatan yang dirasakan seseorang untuk berperilaku sehat (diet atau pengaturan pola makan tinggi vitamin E), maka semakin rendah asupan vitamin E yang dikonsumsi.

Tabel 5. Hasil Uji Korelasi Persepsi dengan

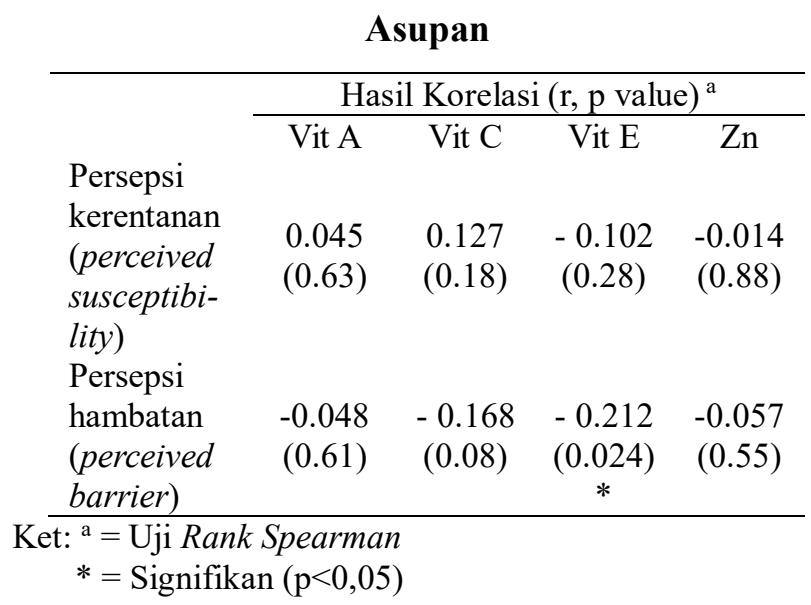


Tabel 4, diketahui bahwa meskipun tidak signifikan secara statistik ( $p$ value masing-masing 0,635 dan 0,178), responden dengan persepsi kerentanan terhadap COVID-19 yang tinggi cenderung lebih banyak mengonsumsi bahan makanan sumber vitamin $\mathrm{A}$ dan $\mathrm{C}$ dibandingkan dengan responden yang memiliki persepsi kerentanan rendah. Hubungan positif ini sesuai dengan penelitian yang dilakukan oleh Nugraha \& Nurhayati (2011), dimana pada pasien ginjal yang merasakan gejala penyakit ginjal secara sering, maka pasien tersebut akan cenderung lebih mematuhi saran atau rekomendasi dokter yang merawatnya. Adanya rasa rentan atau ancaman untuk mengalami suatu penyakit dapat meningkatkan kesiapan dan motivasi seseorang untuk mengubah perilaku hidup menjadi lebih sehat (Szabo \& Piko, 2019).

Adanya persepsi hambatan merupakan salah satu komponen health belief model yang dapat menjelaskan alasan seseorang gagal-untuk berperilaku baik atau sehat, seperti perilaku berhenti merokok, perilaku skrining kesehatan secara rutin, serta peningkatan konsumsi makanan bergizi (Mc Morrow et al., 2016). Hasil penelitian ini menunjukkan bahwa terdapat hubungan negatif yang signifikan antara persepsi hambatan yang dirasakan dengan asupan vitamin E pada responden ( $\mathrm{r}-0,212$, p-value 0,024). Dari hasil uji Rank Spearman juga ditemukan bahwa persepsi hambatan berhubungan negatif dengan asupan vitamin $\mathrm{A}$, vitamin $\mathrm{C}$, dan zink, meskipun tidak signifikan. Hal ini menunjukkan bahwa semakin tinggi skor persepsi yang dimiliki oleh responden Jurnal Gizi Unimus Vol 10 No 12021 (semakin merasa memiliki hambatan), maka semakin rendah pula konsumsi makanan sumber vitamin A, C, E, dan zink. Seperti yang telah dijelaskan sebelumnya, hambatan yang paling banyak dirasakan oleh responden adalah kurangnya biaya untuk membeli bahan makanan karena sebagian besar responden belum bekerja (secara finansial masih bergantung pada orang tua). Hal ini sesuai dengan penelitian yang dilakukan oleh Hupunauet al.(2019), dimanakesulitan atau hambatan yang paling banyak dirasakan oleh seseorang untuk menyediakan makanan yang sehat yaitu mahalnya harga makanan (biaya), akses pembelian yang jauh (jarak), dan keterbatasan produk yang tersedia. Penelitian tersebut jugamenjelaskan bahwa semakin banyak hambatan yang dirasakan seseorang untuk berperilaku sehat, maka semakin tinggi perilaku tidak sehat yang dilakukannya. Hambatan yang dirasakan seseorang tersebut harus segera ditangani, sehingga perilaku hidup sehat akan lebih mudah untuk dijalankan.

\section{KESIMPULAN DAN SARAN}

\section{Kesimpulan}

Asupan vitamin C berbeda secara signifikan antara kelompok yang memiliki persepsi hambatan tinggi dengan kelompok yang memiliki persepsi hambatan rendah. Hasil penelitian ini juga menunjukkan adanya hubungan negatif yang signifikan antara persepsi hambatan yang dimiliki dengan asupan vitamin $\mathrm{E}$ responden. Hal ini mengindikasikan bahwa semakin tinggi hambatan yang dirasakan oleh 
seseorang, maka semakin rendah asupan makanan sumber vitamin E seseorang.

\section{Saran}

Saran yang dapat diberikan dari penelitian ini adalah berupa pemberian edukasi mengenai pentingnya konsumsi antioksidan di masa pandemi COVID-19 kepada seluruh anggota keluarga, terutama pada penyedia makanan utama di rumah (seperti ibu). Selain itu, Pemerintah diharapkan dapat menyediakan subsidi atau bantuan makanan yang tinggi vitamin E dan zink, sehingga masyarakat dapat lebih mudah mengakses makanan tersebut, baik dari segi biaya maupun ketersediaan makanan sehingga hambatan dalam mengonsumsi antioksidan tersebut dapat diminimalisir.

\section{UCAPAN TERIMA KASIH}

Terima kasih ditujukan untuk Berliantin Audina Khabibah, Tsalits Unzillaturrohmah, Faradila Putri Namira, Sheila Weni Astuti, dan Nanda Rizma Faradiba yang telah berkontribusi dan membantu jalannya penelitian ini.

\section{DAFTAR PUSTAKA}

Handayani, D. (2020) 'Asuhan Gizi pada Penyakit Infeksi'. Malang.

Hupunau, R. E., Pradanie, R. and Kusumaningrum, T. (2019) 'Pendekatan Teori Health Belief Model terhadap Perilaku Ibu dalam Pemenuhan Kebutuhan Nutrisi Anak Usia Toddler', Pediomaternal Nursing Journal, 5(1), pp. 1-8.

Jones, C. L. et al. (2015) 'The Health Belief Jurnal Gizi Unimus Vol 10 No 12021
Model as an Explanatory Framework in Communication Research: Exploring Parallel, Serial, and Moderated Mediation', Health Community, 33(4), pp. 395-401. doi: 10.1038/nbt.3121.ChIP-nexus.

Lemeshow, S. et al. (1990) Adequacy of Sample Size in Health Studies. 1st edn, World Health Organization. 1st edn. Chichester: John Wiley \& Sons. doi: 10.1186/1472-6963-14-335.

Mc Morrow, L. et al. (2016) 'Perceived Barriers towards ealthy Eating and Their Association with Fruit and Vegetable Consumption', Journal of Public Health, 39(2), pp. 330-338. doi: 10.1093/pubmed/fdw038.

Muscogiuri, G. et al. (2020) 'Nutritional Recommendations for CoVID-19 Quarantine', European Journal of Clinical Nutrition. Springer US, pp. 10-11. doi: 10.1038/s41430-020-0635-2.

Nugraha, S. and Nurhayati, R. (2011) 'Hubungan Health Belief dengan Perilaku Compliance pada Pasien Gagal Ginjal Kronis di RSUD Al Ihsan', in Prosiding Psikologi. Bandung: Universitas Islam Bandung, pp. 30-39.

Regi, H. D., Karthasurya, M. I. and Suyatno (2017) 'Hubungan Tingkat Kecukupan Vitamin A, C, E, dan Seng sebagai Antioksidan dengan Tekanan Darah Sistolik dan Diastolik pada Ibu Hamil di Puskesmas Bangetayu Kota Semarang', Jurnal Kesehatan Masyarakat, 5(4), pp. 683-689.

Rothan, H. A. and Byrareddy, S. N. (2020) 'The Epidemiology and Pathogenesis of Coronavirus Disease (COVID-19) Outbreak', 
Journal of Autoimmunity. Elsevier,

109(February), p. $102433 . \quad$ doi:

10.1016/j.jaut.2020.102433.

Siswanto, Budisetyawati and Ernawati, F. (2013)

'Peran Beberapa Zat Gizi Mikro dalam Sistem

Imunitas', Gizi Indonesia, 36(1), pp. 57-64.

Syam, F. M., Lubis, Z. and Siregar, M. A. (2013)

'Gambaran Asupan Zat Gizi, Status Gizi, dan

Produktivitas Kerja pada Pekerja Pabrik

Kelapa Sawit Bagerpang Estate PT. PP.

Lonsum', Jurnal Gizi, Kesehatan Reproduksi,

dan Epidemiologi, 2(5).

Szabo, K. and Piko, B. (2019) 'Likelihood of Healthy Eating among Adolescents based on the Health Belief Model', Developments in Health Sciences, 2(1), pp. 22-27. doi: 10.1556/2066.2.2019.004.

Trisnawan, P. D. (2015) Determinan Perilaku

Pencarian Pengobatan pada Mahasiswa Fakultas Kedokteran dan Ilmu Kesehatan UIN Syarif Hidayatullah Jakarta Angkatan Tahun 2013. Universitas Islam Negeri Syarif

Hidayatullah Jakarta.

World Health Organization (2020) WHO

Coronavirus (COVID-19).

$\mathrm{Wu}$, D. et al. (2020) 'The SARS-CoV-2

Outbreak: What We Know', International Journal of Infectious Diseases, 94, pp. 44-48. doi: 10.1016/j.ijid.2020.03.004. 